evidently belong to the Upper Gault (zone of Ammorites rostratus), are very noteworthy.

Lastly, it is remarkable that these sands in the Gault should yield an abundant supply of water. In the case of the Dieppe boring the water rose to about 12 feet above the surface, and at Eu it rose to 50 feet above the surface with a yield of 750,000 litres in the 24 bours.

The beds traversed by the two borings may be summarized thus :-



\title{
INOTIOES OF MEMOIRS.
}

Diprotodon australis. Fossil Remains of Lake Callabonna. Part I : Description of the Manus and Pes of Diprotodon australis. By E. C. Stirling, C.M.G., F.R.S., etc., and A. H. C. Zietz, F.L.S.

IIHIS lavishly illustrated memoir contains the first instalment of the 1 description of the remarkable series of skeletons of Diprotodon discovered some years ago in the dried-up bed of Lake Callabonna in South Australia. A brief account of the discovery was published in Nature (vol. x, 1894, pp. 184 and 206) by Professor Stirling, and a description of the remarkable bird-remains from the same locality has also appeared.

The present memoir deals with the structure of the fore and hind feet, which are almost the only important parts of the skeleton not described by $O$ wen. The collections included a considerable number of more or less complete feet, so that the authors have been able not only to deseribe in great detail the separate bones, but also to give restorations of the manus and pes, both of which exhibit some remarkable characters.

The fore-foot possesses five complete digits, of which the fifth is the largest; the fifth metacarpal has a broad flange-like expansion on its outer side. The pisiform bears more than half the articular surface for the ulna.

The hind-foot also possesses five digits, but the first consists of the metatarsal only. The second and third digits are extremely slender, the fourth only a little stouter, but the fifth is very much thicker, the metatarsal bearing a great flange-like expansion. The whole foot is a most remarkable structure, but, although considerably modified on account of the great weight it had to bear, it still retains distinct marsupial characters.

The general conclusions arrived at by the authors are as follows:-

"Marsupial characters are evident in both the manus and pes of Diprotodon. 
"So far as the individual constituent bones are concerned they present resemblances to their homologous parts in both the Phalangeridæ and the Phascolomyidæ, but the approximation to the former is, on the whole, greater than to the latter.

"On the other hand, regarding the feet as a whole, they, in their shape and proportions as well as in the character and degree of the attenuation of the second and third digits of the pes, are more readily comparable to these members in the Phascolomyidæ.

"With the more specialized pes of the Macropodidze, comparison of that of Diprotodon yields scarcely any points of resemblance, except in so far as the character of the degratation of the hind-feet, similar in kind but varying in degree, affords evidence of the marsupial nature of both."

The memoir is excellently illustrated by a series of eighteen very good photographic plates, including two of the restored manus and pes.

\section{R巴VI巴W $\mathrm{E}$.}

I.-Fossiz Radiolaria. By Dr. G. J. Hinde, F.R.S., F.G.S.

1. "Note on some Radiolarian Chert from the South Uplands of Scotland ": Quart. Journ. Geol. Soc., vol. xlvi (1890), Proc., p. 111, and Ann. Mag. Nat. Hist., ser. vr, rol. vi (1890), p. 40.

2. "Note on the Radiolaria in the Mullion Island Chert." By G. J. Hinde, Ph.D., V.P.G.S. Quart. Journ. Geol. Soc., vol. xlix (1893), pp. 215-218, pl. iv.

3. "Note on a Radiolarian Rock from Fanny Bay, Port Darwin, Australia." By George Jennings Hinde, Ph.D., V.P.G.S. 8vo; pp. 221-226, pl. iv. Quart. Journ. Geol. Soc., vol. xlix (1893).

4. "On a well-marked Horizon of Radiolarian Rocks in the Lower Culm-measures of Devon, Cornwall, and West Somerset." By G. J. Hinde, Ph.D., F.R.S., F.G.S., and Howard Fox, Esq., F.G.S. 8vo; pp. 609-667, pls. xxiii-xxviii. Quart. Journ. Geol. Soc., vol. li (1895). Supplementary Note, etc., Trans. Devon Assoc., vol. xxviii (1896), pp. 774-789.

5. "On the Radiolaria in the Devonian Rocks of New South Wales." By G. J. Hinde, Ph.D., F.R.S., F.G.S. 8vo; pp. 38-63, pls. viii and ix. Quart. Journ. Geol. Soc., vol. lv (1899).

6. "On Radiolaria in Chert from Chypon's Farm, Mullion Parish, Cornwall." By George Jennings Hinde, Ph.D., F.R.S., F.G.S. 8vo; pp. 214-219, pl. xvi. Quart. Journ. Geol. Soc., vol. Iv (1899).

7. "Description of Fossil Radiolaria from the Rocks of Central Borneo." By Dr. George J. Hinde. 4to; 36 pp., with 4 plates. (E. J. Brill, Leyden ; and H. Gerlings, Amsterdam : 1899.)

1. MONG the various minute aquatic organisms that have persistent A structure within or without their bodies, several kinds have been recognized by naturalists, with more or less exact discrimination, since natural history became a definite study, after the dark ages of 